\title{
Functional composition of subtropical highland forests in different successional stages in southern Brazil
}

\author{
Composición funcional de bosques subtropicales de alta montaña \\ en diferentes estados sucesionales en el sur de Brasil
}

\author{
Maiara Fortuna Silveira a, Ana Carolina da Silva a, Edilaine Duarte a, Luran Monteiro Muzeka a, \\ Janaina Gabriela Larsen a, Vanderlei dos Santos a, Queli Cristina Lovatel a, Pedro Higuchi a* \\ *Corresponding author: a Universidade do Estado de Santa Catarina, Departamento de Engenharia Florestal, \\ Av. Luiz de Camões, 2090, Lages, Brasil, phone: 55-49-32899308, pedro.higuchi@udesc.br
}

\begin{abstract}
SUMMARY
Ecological succession is one of the most important processes in forest ecosystems, still poorly understood in the highland Araucaria forests of Southern Brazil. Here we investigated this process by describing functional composition changes in response to a vegetation successional mosaic in four forest fragments in the municipality of Urubici, State of Santa Catarina, Brazil. Two fragments were classified as in advanced stage of succession and two were classified in early stage. The following functional traits were determined: wood density, leaf area, specific leaf area, dispersal syndrome and leaf phenology. For each fragment, we determined the community weighted mean (CWM) and the functional diversity (RaoQ). Data were analyzed by descriptive statistics, $t$ and Mann-Whitney tests and Principal Components Analysis. We found that the successional stage is a relevant source of functional heterogeneity. At the advanced-successional stage, tree communities have harder woods, more membranous and semi-deciduous leaves and higher functional diversity. Conversely, at the early successional stages, forests have softer wood, more coriaceous leaves and lower functional diversity. We concluded that the studied forests showed a high functional composition heterogeneity, partially determined by a successional mosaic. While perennial species with lower values of specific leaf area and wood density predominated in the early successional areas, semi-deciduous species with higher values of specific leaf area and wood density prevailed in the late successional ones.
\end{abstract}

Key words: highland forests, araucaria forest, functional diversity, functional heterogeneity, successional mosaic.

\section{RESUMEN}

La sucesión ecológica es uno de los procesos más importantes en los ecosistemas forestales, aún poco conocido en los bosques de Araucaria del sur de Brasil. Con el objetivo de evaluar la organización funcional del componente arbóreo en diferentes estados sucesionales, el presente estudio fue realizado en cuatro fragmentos de bosque de araucaria de alta montaña en el Parque Nacional São Joaquim, en el municipio de Urubici, estado de Santa Catarina. Dos fragmentos fueron considerados en avanzado estado de sucesión y dos en una etapa inicial. Se determinaron los siguientes atributos funcionales: densidad de madera, área foliar, área foliar específica, síndrome de dispersión y régimen de renovación foliar. Para cada fragmento, se determinaron la media ponderada de las comunidades (CWM) y la diversidad funcional (RaoQ). Los datos fueron analizados por medio de estadísticas descriptivas, pruebas t y Mann-Whitney, y análisis de componentes principales. Observamos que la etapa sucesional es una fuente relevante de heterogeneidad funcional. En la fase de sucesión avanzada, las comunidades arbóreas tienen maderas más duras, hojas más membranosas y semicaducifolias, y una mayor diversidad funcional. En las fases sucesionales iniciales, los bosques tienen una madera más suave, hojas más coriáceas y una menor diversidad funcional. Concluimos que los bosques estudiados mostraban una alta heterogeneidad de composición funcional, parcialmente determinada por el mosaico sucesional. Mientras que las especies perennes con valores más bajos de área foliar específica y de densidad de madera predominaron en las partes de sucesión inicial, las especies semicaducifolias con valores más altos de área foliar específica y de densidad de madera prevalecieron en las de sucesión tardía.

Palabras clave: bosques montanos, bosque de araucarias, diversidad funcional, heterogeneidad funcional, mosaico sucesional.

\section{INTRODUCTION}

Ecological succession is recognized as one of the primary mechanisms to promote spatial and temporal heterogeneity in forest ecosystems, thus being a theme of high interest in ecological studies since the last century (Mi- chaud et al. 2015). Succession begins from the occurrence of disturbances and is influenced by deterministic and stochastic factors such as the land-use history, soils, climate, source of propagules and the priority effect (Schantz et al. 2015). Thus, succession is a multidirectional process with variable speed that is evidenced from a heterogeneous ve- 
getation mosaic (Arroyo-Rodriguez et al. 2017). Given its importance, studies addressing ecological processes at different succession stages are fundamental for a better understanding of forest functioning.

Recently, several studies have investigated the functional structure of tree communities along a successional chronosequence (e.g. Lohbeck et al. 2014). Functional traits influence organisms' development and impact ecosystem services, such as nutrient cycling and carbon sequestration (Cornwell et al. 2008). The functional description of communities allows greater understanding of the forest succession process, allowing inference regarding the performance of key ecological factors, such as environmental filters and limiting similarity (Lohbeck et al. 2014).

According to functional traits, plants can be classified based on their strategies of resource acquisition and use as conservative or acquisitive (Donovan et al. 2011). Trees with acquisitive strategies have faster growth, shorter lifespan, larger specific leaf area, higher photosynthetic rate and lower wood density. On the other hand, those with conservative strategies usually have slower growth, longer life span, smaller specific leaf area, lower photosynthetic rate and higher wood density (Donovan et al. 2011).

Succession is expected to be accompanied by changes in the functional traits of tree species communities (Alvarez-Añorve et al. 2012). The environmental condition of a forest under post-disturbance early succession is characterized by increased light availability and more extreme microclimate conditions (Lebrija-Trejos et al. 2011). Therefore, it is expected that species at early succession stages show functional traits that allow them to overcome these environmental limitations, resulting in low functional diversity (Alvarez-Añorve et al. 2012, Lohbeck et al. 2014). In contrast, at late succession stages, the understory conditions provide an environment with more shadow and less extreme microclimate conditions, and offer different forest strata, facilitating the establishment of species with different functional traits, resulting in higher functional diversity (Alvarez-Añorve et al. 2012, Lohbeck et al. 2014).

Despite the several studies conducted in tropical regions (e.g. Alvarez-Añorve et al. 2012, Arroyo-Rodriguez et al. 2017), little is still known about the successional process in peripheral areas, such as subtropical montane and high montane forests, which are currently endangered by global warming (e.g. Carlucci et al. 2011). Because of this, knowing how this process operates in the Subtropical Brazilian Atlantic Forest, a world hotspot for biodiversity conservation, is of high interest. These forests occur in the landscape along with grasslands, both natural, remnants of the last glacial period and resulting from deforestation for grazing and agricultural practices (Galvão and Augustin 2011). These environments harbor Araucaria angustifolia (Bertol.) Kuntze, a gymnosperm tree that is currently endangered due to the increased reduction of its population as a result of the predatory exploitation occurred mainly in the mid-last century. Although protected by law, Araucaria forests are under chronic anthropogenic pressure, subject to cattle grazing. Because this forest occurs in subtropical latitudes and relatively high altitude ( $\sim 1500 \mathrm{~m}$ a.s.1.), winter frosts are frequent and partly explains the peculiar floristic composition and low species diversity of these areas (França and Stehmann 2004).

In this context, we intend to further the knowledge on the ecological processes linked to forest succession in a still poorly studied region of the Brazilian Atlantic Forest by investigating the tree community functional composition. We aimed at evaluating how the successional mosaic affects the tree component's functional heterogeneity in forest remnants. We expect a lower functional diversity in the early stage areas because of the supposed higher intensity of environmental filters.

\section{METHODS}

Characteristics of the study areas. This study was conducted in four fragments of Upper Montane Subtropical Mixed Forest (Araucaria Forests) in São Joaquim National Park (figure 1). This park was created in 1961 with the goal of protecting remnants of Araucaria Forests. It covers some municipalities of Santa Catarina State, Brazil, including Urubici, where the present survey was conducted. The studied areas are located from 1,300 to $1,600 \mathrm{~m}$ a.s.l. (table 1). The park is predominantly formed by a mosaic of grasslands and forests.

Climate in the region is $\mathrm{Cfb}$ according to the Köppen's classification, with no dry season. Annual average temperature ranges from 11 to $15^{\circ} \mathrm{C}$, with low temperatures in the winter, favoring the occurrence of frost and snow; annual rainfall and air relative humidity are approximately $1,370 \mathrm{~mm}$ and $80 \%$, respectively. There is a predominance of Leptsols and Cambisols in slightly to strongly undulated relief.

Characterization of the succession stages and information on the history of the areas were provided by the Park administration and through field observations, with the latter based on the studies by Duarte et al. (2018), who assessed some of these forest fragments (Silveira et al. 2021).

Study areas 1 and 3, which are located at approximately $1,600 \mathrm{~m}$ a.s.l., are at a late stage of succession, presenting mainly secondary and late species. The proportions of species classified as secondary and climax in these regions are $72.73 \%$ (area 1 ) and $81.25 \%$ (area 3 ). These areas present patches that were deforested in the 1960 s to be transformed into pasture for cattle.

Study areas 2 and 4, which are located at approximately $1,300 \mathrm{~m}$ a.s.l., are at an early stage of succession, comprising mainly pioneer species $(57.14 \%$ in area 2 and $52.94 \%$ in area 4). These areas present a more intense history of soil use and management, resulting from deforestation in the 1960s. Livestock has always been the most im- 
portant rural activity in these areas. It is worth highlighting that the late succession stage areas are located at higher altitudes and have undergone less anthropogenic activity because of difficulty of access, thus being more preserved.

Data collection. The forest fragments had been previously inventoried by the Dendrology and Phytosociology Laboratory of Santa Catarina State University (LABDENDRO/ UDESC) in previous studies. For these inventories, a 20 $\mathrm{x} 100 \mathrm{~m}$ transect was installed in each fragment, and they were subdivided into 20 plots of $10 \times 10 \mathrm{~m}$. All transects were arranged perpendicularly to the edge, towards the in- terior of each fragment. In each plot, all individuals with DBH (diameter at breast height) $\geq 5 \mathrm{~cm}$ were identified and quantified. Sampled species whose individuals represented at least $80 \%$ of the abundance observed in the areas were selected for functional characterization. Because of the floristic-structural differences in each area (Silveira et al. 2021), we had distinct numbers of functionally described species. In total, 23 species belonging to 15 botanical families were selected: 11 in area 1 , four in area 2 , seven in area 3 , and nine in area 4.

For each of the selected species, five functional traits considered important in Upper Montane Ombrophilous

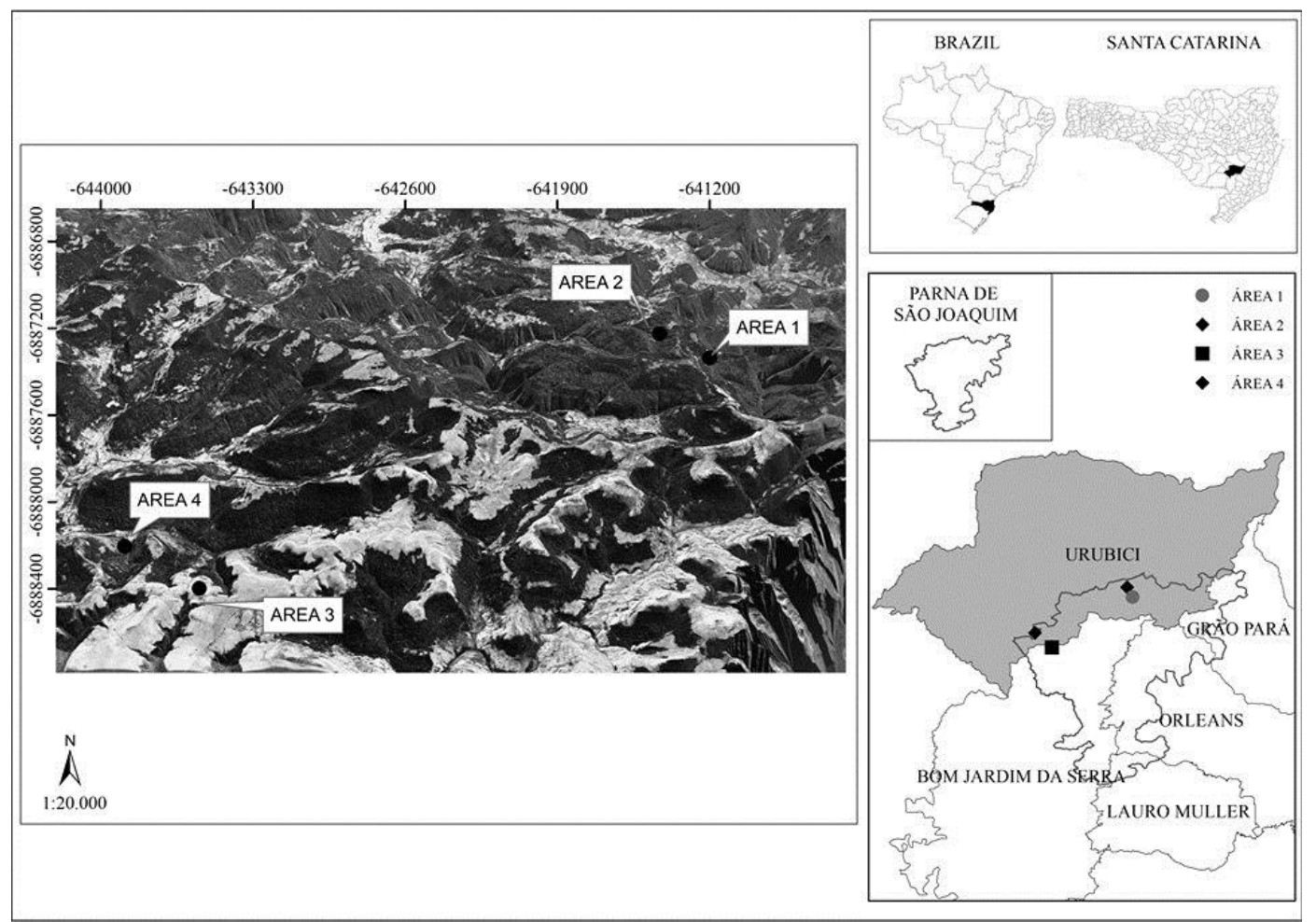

Figure 1. Location of the studied highland Araucaria forests at São Joaquim National Park, Southern Brazil. sur de Brasil.

Mapa de la ubicación de los cuatro fragmentos de bosques subtropicales de alta montaña inventariados en el Parque Nacional São Joaquim,

Table 1. Highland Araucaria forests at São Joaquim National Park, where functional characterization data were obtained, with their respective geographical coordinates, mean altitudes (Alt) and succession stages.

Áreas de bosque subtropicales de alta montaña ubicadas en el Parque Nacional São Joaquim, sur de Brasil, donde se obtuvieron datos de caracterización funcional, con sus respectivas coordenadas geográficas, altitud media (Alt) y etapa de sucesión.

\begin{tabular}{ccccc}
\hline Area & Geographic coordinates & Area (ha) & Altitude $(\mathrm{m})$ & Successional Stages \\
\hline Area 1 & $28^{\circ} 05^{\prime} 41.5^{\prime} \mathrm{S} ; 49^{\circ} 30^{\prime} 14.71$ ' W & 12 & 1,628 & Advanced \\
Area 2 & $28^{\circ} 04^{\prime} 46.87^{\prime \prime} \mathrm{S} ; 49^{\circ} 30^{\prime} 51.29^{\prime \prime} \mathrm{W}$ & 35 & 1,356 & Initial \\
Area 3 & $28^{\circ} 09^{\prime} 49.19^{\prime \prime} \mathrm{S} ; 49^{\circ} 36^{\prime} 47.56^{\prime \prime} \mathrm{W}$ & 2 & 1,660 & Advanced \\
Area 4 & $28^{\circ} 08^{\prime} 44.00^{\prime \prime} \mathrm{S} ; 49^{\circ} 37^{\prime} 27^{\prime \prime} \mathrm{W}$ & 5 & 1,300 & Initial \\
\hline
\end{tabular}


Forest were assessed: wood density $\left(\mathrm{g} / \mathrm{cm}^{3}\right)$, leaf area $\left(\mathrm{cm}^{2}\right)$, specific leaf area $\left(\mathrm{cm}^{2} / \mathrm{g}\right)$, dispersion syndrome (zoochoric, anemochoric or autochoric) and leaf renovation regime (deciduous, semi-deciduous or evergreen).

For each species, wood samples were collected from five individuals (DBH of 10 to $30 \mathrm{~cm}$ ) by an increment borer with a diameter of $5.15 \mathrm{~mm}$. For species with small diameter stems (e.g. Baccharis uncinella DC.), wood samples, with a length of $10 \mathrm{~cm}$, were taken at ground level. All samples were placed in water recipients until a constant wet mass. The weight of the wet mass was determined by the Archimedes principle. Afterwards, the samples were dried at a temperature of $100{ }^{\circ} \mathrm{C}$, and subsequently weighed on an analytical scale. Thus, the wood basic density was determined by the ratio between the dry mass $(\mathrm{g})$ and wet mass (g).

The leaf area and the specific leaf area were obtained by collecting 20 leaves from 10 individuals per species and per fragment, including the petioles and, for composite leaves, rachises, following the protocol proposed by Pérez-Harguindeguy et al. (2013). Leaves were collected from the tree top median third from individuals with superior light incidence, avoiding collection of young, herbivorated and unhealthy leaves, giving preference to healthier leaves. Leaf area and the mean leaf area values by species and fragment were then calculated. In the laboratory, the leaves were stored in oven until constant dry mass was reached and later weighed in an analytical scale. Specific leaf area was obtained by the ratio between leaf area $\left(\mathrm{cm}^{2}\right)$ and leaf dry mass $(\mathrm{g})$. The mean of the specific leaf areas for each species per fragment was also calculated.

Species were classified according to the following dispersal syndromes: zoochoric, anemochoric or autochoric. These were determined through field observation and literature review (Carvalho 2003). Considering the data obtained, species were classified as zoochoric or non-zoochoric.

Leaf renovation regime of the species was evaluated through field observation as follows: in an unfavorable period, species with loss of up to $20 \%$ of their leaves were classified as perennial; those with loss from 20 to $50 \%$ of their leaves were classified as semi-deciduous, and species with loss $>50 \%$ of their leaves were classified as deciduous.

Data analyses. To evaluate the functional composition patterns of the tree communities and compare the two succession stages (early and late), the traits community weighted mean (CWM) was calculated for each sampling plot. Data normality was verified using the Shapiro-Wilk test. Data with a normal distribution were compared by the Student's t-test, and those without normal distribution were evaluated with the Mann-Whitney test.

Based on CWM values, we performed the functional grouping of the plots belonging to each of the succession stages using the Principal Components Analysis (PCA) proposed by Hill and Smith (1976), which enabled the inclusion of categorical data (leaf renovation and syndrome of seed dispersion) in the analysis.
Functional diversity was determined by the RaoQ index. The normality of RaoQ values was verified using the Shapiro-Wilk test. Differences between the succession stages were evaluated by the Mann-Whitney test. All analyses were processed in R (R Core Team 2019).

\section{RESULTS}

We observed variation in functional traits between species and succession stages (table 2). Species occurring in late successional areas showed higher values of wood density $(P=0.07)$ and specific leaf area $(P=0.06)$. This suggests that species have different resource acquisition strategies depending on the successional stage at which they are inserted. Most of the species were classified as zoochoric and perennial, and these characteristics predominated in both early and late succession stages.

The 13 most abundant species in the areas at the late succession stage belonged to the Myrtaceae family. The 11 most abundant species in the areas at the early succession stage showed more homogenous distribution per family, with no family outstanding in richness.

The species with the highest wood density (WD) were Eugenia uruguayensis $\left(0.83 \mathrm{~g} / \mathrm{cm}^{3}\right)$ in the late succession stage areas, and Mimosa scabrella $\left(0.79 \mathrm{~g} / \mathrm{cm}^{3}\right)$ in the early succession stage areas, whereas those with the lowest WD mean values were Drimys angustifolia $\left(0.57 \mathrm{~g} / \mathrm{cm}^{3}\right)$ and Styrax leprosus $\left(0.38 \mathrm{~g} / \mathrm{cm}^{3}\right)$ in the late and early succession stage areas, respectively.

Regarding the leaf area (LA), among the early succession stage areas, Mimosa scabrella and Citronella gongon$h a$ presented the highest values, with 30.41 and $20.61 \mathrm{~cm}^{2}$, respectively. In the late succession stage areas those with the highest values were Prunus myrtifolia $\left(15.71 \mathrm{~cm}^{2}\right)$ and Myrceugenia myrcioides $\left(14.26 \mathrm{~cm}^{2}\right)$. Among the species with smaller leaf areas, Siphoneugena reitzii $\left(0.65 \mathrm{~cm}^{2}\right)$ and Baccharis uncinella $\left(0.28 \mathrm{~cm}^{2}\right)$ stood out in the late and early succession stage areas, respectively.

The species in late succession stage areas with more membranous leaves (i.e. higher values of specific leaf area SLA) were Myrceugenia miersiana $\left(139.41 \mathrm{~cm}^{2} / \mathrm{g}\right)$ and $M y r-$ ceugenia regnelliana $\left(120.14 \mathrm{~cm}^{2} / \mathrm{g}\right)$, whereas Ilex microdonta $\left(74.09 \mathrm{~cm}^{2} / \mathrm{g}\right)$ was the species with more coriaceous leaves (i.e. lower values of specific leaf area). For the early succession stage areas, the highest SLA value was observed in Podocarpus lambertii $\left(123.19 \mathrm{~cm}^{2} / \mathrm{g}\right)$ and the lowest value was found in Citronella gongonha $\left(46.12 \mathrm{~cm}^{2} / \mathrm{g}\right)$.

In the functional ordination of the plots based on their CWM values (figure 2), axes 1 and 2 explained together $80.84 \%$ of the total data variation. Axis $1(51.94 \%$ explanation) indicated a gradient associated predominantly with dispersion syndrome (non-zoochoric species $=1.17$ ), leaf area (0.57) and wood density (0.52). On the right side of the ordination, there were plots with dominance of nonzoochoric species and higher values of leaf area and wood density. On the left side of the ordination, plots with op- 
posite characteristics (zoochoric dispersion syndrome and lower values of leaf area and wood density) were observed. In turn, Axis 2 (28.90\% explanation) synthesized a gradient associated predominantly with leaf renovation regime (semi-deciduous species $=-0.92$ ) and specific leaf area $(-0.73)$. Plots in the upper part of the ordination presented dominance of perennial species and smaller specific leaf area, whereas those in the lower part of the ordination showed predominance of semi-deciduous species with larger specific leaf area. The plots located in areas at the late succession stage, which predominantly occupied the lower part of the ordination, had higher values of specific leaf area (more membranous leaves) and semi-deciduous species. Lower values of SLA (more coriaceous leaves) and perennial species were associated with species in the areas at early succession stage.

Functional diversity (RaoQ index) was lower in the early succession stage areas (0.03) than in the late succession stage areas (0.05) (figure 3), indicating lower amplitude of the functional traits evaluated at the beginning of the post-disturbance recovery process compared with that in later phases.

Table 2. Functional traits of the 23 most abundant tree species, separated by succession stage (EA = early succession stage area and LA = late succession stage area), in fragments of highland Araucaria forests at São Joaquim National Park.

Características funcionales de las 23 especies arbóreas más abundantes muestreadas, separadas por etapa de sucesión (AI = áreas iniciales y TA = áreas tardías), en áreas de bosques subtropicales de alta montaña en el Parque Nacional São Joaquim, sur de Brasil.

\begin{tabular}{|c|c|c|c|c|c|c|c|c|}
\hline \multirow{2}{*}{ Species } & \multicolumn{2}{|c|}{ WD } & \multicolumn{2}{|c|}{ LA } & \multicolumn{2}{|c|}{ SLA } & \multirow{2}{*}{ DS } & \multirow{2}{*}{ LR } \\
\hline & EA & LA & EA & LA & EA & LA & & \\
\hline Acca sellowiana (O.Berg) Burret & 0.64 & - & 17.77 & - & 70.10 & - & $\mathrm{Z}$ & $\mathrm{P}$ \\
\hline Araucaria angustifolia (Bertol.) Kuntze & 0.57 & - & 1.90 & - & 51.29 & - & $\mathrm{Z}$ & $\mathrm{P}$ \\
\hline Baccharis uncinella DC. & 0.65 & - & 0.28 & - & 74.33 & - & A & $\mathrm{P}$ \\
\hline Berberis laurina Thunb. & 0.67 & - & 10.28 & - & 78.87 & - & $\mathrm{Z}$ & $\mathrm{P}$ \\
\hline Citronella gongonha (Mart.) R.A.Howard & 0.63 & - & 20.61 & - & 46.12 & - & $\mathrm{Z}$ & $\mathrm{P}$ \\
\hline Crinodendron brasiliense Reitz et L.B.Sm. & - & 0.58 & - & 5.05 & - & 99.40 & A & SD \\
\hline Drimys angustifolia Miers. & 0.60 & 0.57 & 5.60 & 5.60 & 90.07 & 93.05 & $\mathrm{Z}$ & SD \\
\hline Drimys brasiliensis Miers. & 0.41 & - & 17.33 & - & 69.17 & - & $\mathrm{Z}$ & SD \\
\hline Eugenia uruguayensis Cambess. & - & 0.83 & - & 7.23 & - & 74.09 & $\mathrm{Z}$ & $\mathrm{P}$ \\
\hline Ilex microdonta Reisse & - & 0.80 & - & 5.71 & - & 66.64 & Z & $\mathrm{P}$ \\
\hline Lithraea brasiliensis Marchan & 0.78 & - & 6.61 & - & 67.82 & - & $\mathrm{Z}$ & $\mathrm{P}$ \\
\hline Mimosa scabrella Benth & 0.79 & - & 30.41 & - & 81.74 & - & $\mathrm{Au}$ & $\mathrm{P}$ \\
\hline Myrceugenia mesomischa (Burret) D.Legrand et Kausel & - & 0.65 & - & 4.34 & - & 92.67 & $\mathrm{Z}$ & $\mathrm{P}$ \\
\hline Myrceugenia miersiana (Gardner) D.Legrand et Kausel & - & 0.63 & - & 9.78 & - & 139.41 & $\mathrm{Z}$ & SD \\
\hline Myrceugenia myrcioides (Cambess.) O.Berg & - & 0.71 & - & 14.26 & - & 102.81 & $\mathrm{Z}$ & SD \\
\hline Myrceugenia oxysepala (Burret) D.Legrand et Kausel & - & 0.66 & - & 4.07 & - & 106.95 & $\mathrm{Z}$ & $\mathrm{P}$ \\
\hline Myrceugenia regnelliana (O.Berg) D.Legrand et Kausel & - & 0.69 & - & 1.47 & - & 120.14 & Z & $\mathrm{P}$ \\
\hline Ocotea pulchella (Nees et Mart.) Mez & - & 0.71 & - & 3.99 & - & 74.01 & Z & $\mathrm{P}$ \\
\hline Podocarpus lambertii Klotzsch ex Endl. & 0.46 & - & 1.98 & - & 123.19 & - & Z & $\mathrm{P}$ \\
\hline Prunus myrtifolia (L.) Urb. & - & 0.79 & - & 15.71 & - & 77.10 & $\mathrm{Z}$ & $\mathrm{P}$ \\
\hline Siphoneugena reitzii D.Legrand & - & 0.67 & - & 0.65 & - & 85.23 & Z & $\mathrm{P}$ \\
\hline Styrax leprosus Hook. et Arn. & 0.38 & - & 12.32 & - & 102.71 & - & $\mathrm{Z}$ & $\mathrm{P}$ \\
\hline Weinmannia paulliniifolia Pohl ex Ser. & - & 0.63 & - & 8.51 & - & 103.80 & A & $\mathrm{P}$ \\
\hline Mean & 0.60 & $0.69^{*}$ & 11.37 & 6.64 & 77.86 & $95.02^{*}$ & 0 & 0 \\
\hline
\end{tabular}

Where: $\mathrm{LA}=$ leaf area $\left(\mathrm{cm}^{2}\right) ; \mathrm{SLA}=$ specific leaf area $\left(\mathrm{cm}^{2} / \mathrm{g}\right) ; \mathrm{WD}=$ wood density $\left(\mathrm{g} / \mathrm{cm}^{3}\right) ; \mathrm{DS}=$ dispersion syndrome $(\mathrm{Z}=$ zoochoric, $\mathrm{A}=$ anemochoric, and $\mathrm{Au}=$ autochoric $) ; \mathrm{LR}=$ leaf renovation regime $(\mathrm{P}=$ perennial, $\mathrm{D}=$ deciduous, and $\mathrm{SD}=$ semi-deciduous $)$. "Indicates differences in the mean values of the functional traits of the species according to succession stage by the Student's $t$ or Mann-Whitney tests, with $90 \%$ confidence interval. 


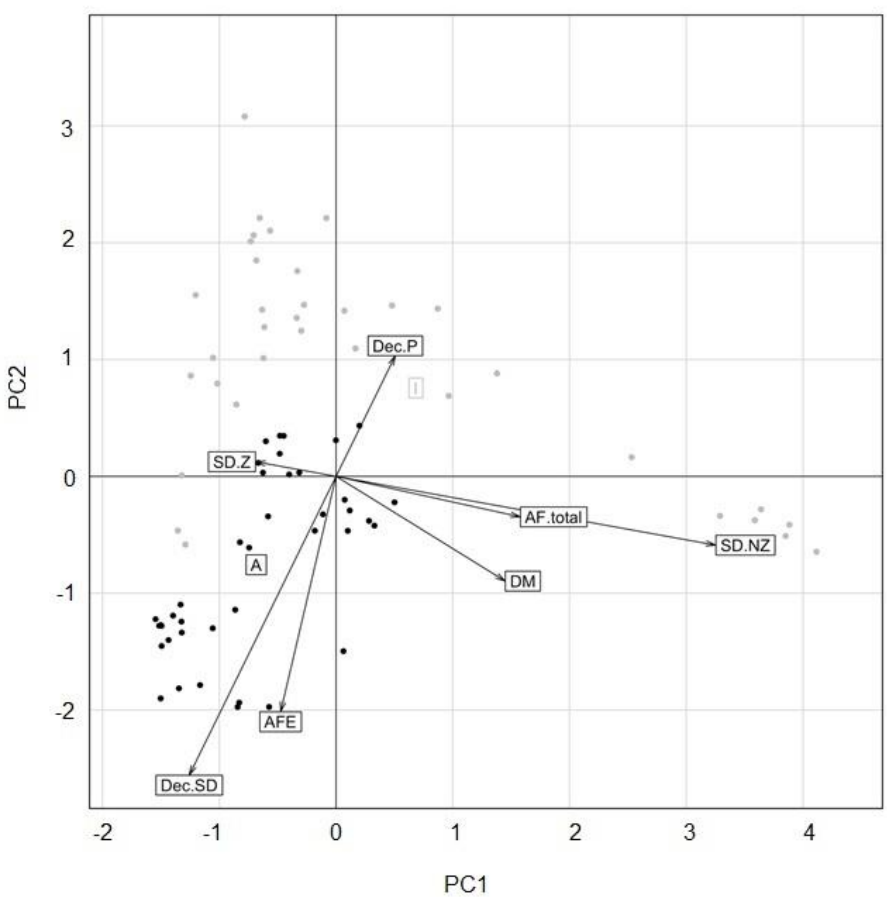

Figure 2. Ordination of initial (I - gray) and advanced plots (A - black), produced by the Principal Component Analysis (PCA), based on functional traits obtained from the most abundant species in fragments of highland Araucaria forests at São Joaquim National Park, Southern Brazil. Dec.P = perennial leaves; Dec. $\mathrm{SD}=$ semi-deciduous leaves; $\mathrm{DM}=$ wood basic density; $\mathrm{AF}=$ leaf area; $\mathrm{AFE}=\mathrm{specific}$ leaf area; $\mathrm{SD} . \mathrm{Z}=$ zoochoric dispersal syndrome; SD.NZ = non-zoochoric dispersal syndrome.

Ordenación de las parcelas en fases iniciales (I, grises) y avanzadas (A, negras), producidas por el Análisis de Componentes Principales (PCA), relacionadas con atributos funcionales obtenidos de las especies de mayor abundancia en áreas de bosque subtropicales de alta montaña en el Parque Nacional São Joaquim, sur de Brasil. Donde: Dec. $\mathrm{P}=$ hojas perennes; Dec.SD = hojas semideciduas; DM = densidad básica de madera; AF total = área foliar; $\mathrm{AFE}=$ área foliar específica; $\mathrm{SD} . \mathrm{Z}=$ síndrome de dispersión zoocórica y SD.NZ = síndrome de dispersión no zoocórica.

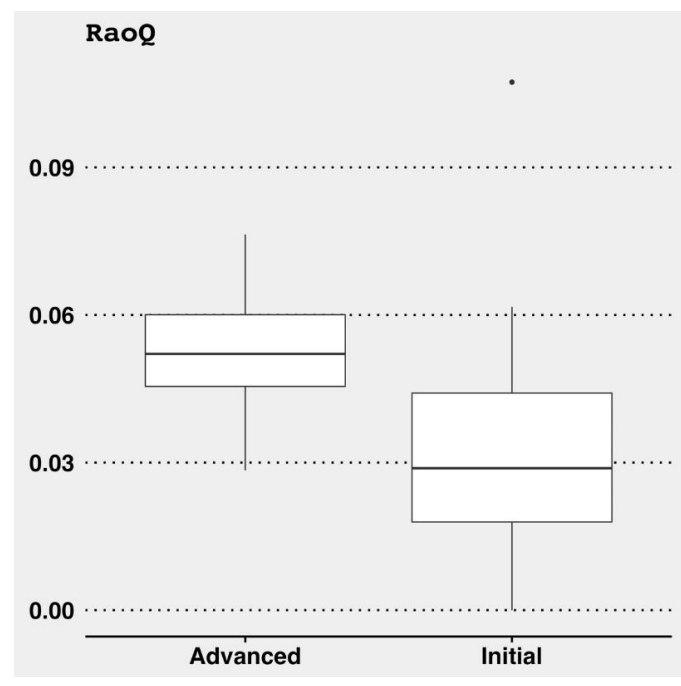

Figure 3. Boxplot for functional diversity (RaoQ index) comparison between areas presenting initial and advanced succession stages in fragments of highland Araucaria forests at São Joaquim National Park, Southern Brazil.

Boxplot para la comparación de la diversidad funcional de áreas en fase inicial y tardía, determinada por el índice RaoQ, obtenida en áreas de bosque subtropicales de alta montaña en el Parque Nacional São Joaquim, sur de Brasil.

\section{DISCUSSION}

Our results showed that the tree communities at different stages of succession presented differences in their functional composition, especially related to the wood density (higher in the late and lower in the early stage areas), specific leaf area (more coriaceous leaves in the early and more membranous in the late stage areas), and leaf renovation regime (semi-deciduous leaves in the late and perennial in the early stage areas). During the process of succession, the assemblage of a tree species community undergoes different intensities of ecological forces related to environmental filters and limiting similarity (Lohbeck et al. 2014). Given the heterogeneity in composition and functional diversity observed, the present study corroborated the above aspects.

Despite the evident influence of altitude on the functional variations of the species in the region (Soboleski et al. 2017), in our study, we observed a pattern opposite to the expected one, with higher altitude areas presenting tree communities with greater values of specific leaf area and wood density, semi-deciduous renovation regime of leaves, and better functional diversity. As highlighted by Soboleski et al. (2017), at higher altitudes, the Araucaria Fo- 
rest is expected to have a tree component with functional traits that allow the trees to survive in colder environments (e.g. smaller and more coriaceous leaves). However, the contrasting pattern observed here underlines the idea that the functional heterogeneity is also influenced by a disturbances regime, which, by acting on a local scale, causes microclimatic alterations. Particularly in the study region, more open sites, like those in an early succession stage, have a more adverse microclimate for trees regeneration, such as higher frost frequency (Dreyer et al. 2020). This fact could explain the predominance of smaller and more coriaceous leaves, even at a lower altitude.

The early succession stage areas were composed mostly of pioneer species such as Baccharis uncinella and Mimosa scabrella, which present fast growth and short lifespan (Turner 2001). Studies in humid tropical forests have shown that species belonging to this functional group will produce low-cost leaves with high photosynthetic rates, although with a short life span (Donovan et al. 2011), characteristics associated with acquisitive strategies, in which there is a rapid use of resources (Donovan et al. 2011). According to some authors (e.g. Donovan et al. 2011), species with acquisitive strategies are more abundant in the beginning of succession since there is more availability of light.

Remarkably, our findings, conducted in high montane and subtropical climate area, differed from those observed in humid tropical forests (Donovan et al. 2011), showing that the succession process should not be generalized. This can be explained by the fact that the initial succession areas in the higher altitude regions of southern Brazil have highly hostile microclimatic conditions for tree establishment, with frequent frosts, high wind turbulence and large daily thermal amplitudes. Thus, the investment in protecting the leaves, with more leathery leaves, which is a conservative strategy of stress tolerant species (Grime 1977), may explain the pattern found for the more initial areas. According to Cornelissen et al. (2003), low values of SLA indicate that plants are investing more in structural components, which increase their resistance against desiccation and herbivory and, in the case of the present study, against frosting. Boeger et al. (2009), when studying leaves of Miconia sellowiana (DC.) Naudim in communities at different stages of succession in Paraná State, Brazil, verified that in the early succession stage leaves are usually thicker and with smaller specific leaf area - a pattern similar to that found in this study.

Leaf renovation is associated with climatic seasonality throughout the year (Givnish 1987), efficiency of use of nutrients by plants (Pérez-Harguindeguy et al. 2013) and physical and chemical characteristics of the soil. Perennial leaves can be also considered as a conservative strategy. The dominance of this trait in initial successional areas may indicate non-evaluated soil variations since species that have leaves of this nature are associated with places with more scarce resources (Reich et al. 1992).
Low wood density values were found for the species in the early succession stage areas, which is expected since these are fast-growing species with lower wood mechanical resistance (Zanne et al. 2010), confirming the investment in acquisitive strategies. The opposite is also expected in areas at the late succession stage, with slow-growing species with high wood density, typical of those with conservative strategies. According to Donovan et al. (2011), in the more structured later successional areas, species with conservative strategies predominate. This increase in wood density may be related to stressful factors, such as low solar radiation, winds, low temperatures and low soil fertility (Chave et al. 2006), which are conditions observed in the nebular forests of southern Brazil.

When considered within each successional condition, it can be observed that the distribution of species also varies according to the studied traits. Mimosa scabrella, for example, presented higher wood density in early succession stage areas. This species presents the anemochoric dispersion syndrome, which is characteristic of species at early succession stages. Contrasting results were found for Styrax leprosus, with bird-dispersed fruits and soft wood. In turn, Crinodendron brasiliense and Eugenia uruguayensis stood out among the areas in the late succession stage. Crinodendron brasiliense, an endemic species in high altitude regions of the South Plateau of Santa Catarina State (Duarte et al. 2018), has wind-dispersed fruits and soft wood. On the other hand, E. uruguayensis, like many other Myrtaceae species, has high wood density and animal dispersed fruits.

The functional ordination showed that plots in the early succession stage areas presented high dispersion in the bi-dimensional ordering space, especially along transect 1, suggesting an expressive functional variation. In turn, analysis of functional diversity using the RaoQ index showed that the same plots at early succession stage presented lower values compared with those of the plots at late succession stage. Thus, it can be inferred that late succession stage areas present functionally similar plots with co-existence of species belonging to different functional groups (i.e. canopy and understory), whereas early succession stage areas are characterized by species of different functional groups (i.e. grouping of individuals of the M. scabrella and Baccharis genera) that did not coexist in the same plots. This pattern illustrates the complexity of the functional structuring process of the existing tree communities, indicating that the ecological factors of interspecific competition and environmental filtering act differently according to the stage of succession considered (Lebrija-Trejos et al. 2011, Lohbeck et al. 2014). In this context, one can infer that areas with higher functional diversity (RaoQ) - at late succession stage - are more resilient to disturbances (Walker et al. 1999), more efficient in using resources and present more environmental functions (Mason et al. 2005). 


\section{CONCLUSIONS}

The evaluated fragments of upper montane forest were characterized by high heterogeneity of functional composition, partly determined by the existing successional patches. Functional traits provided useful information for the successional description of the studied areas of subtropical upper montane forests. At the early succession stage, we observed the predominance of perennial species with low values of specific leaf area and wood density; whereas in those at the late succession stage, there was a predominance of semi-deciduous species with higher values of specific leaf area and wood density. This pattern suggests that the species showed different life strategies. Since the areas at the early succession stage showed lower functional diversity (RaoQ) than that presented by the later ones, our hypothesis was accepted.

\section{ACKNOWLEDGMENTS}

The authors are grateful to CNPq for the grant in research productivity provided to the second and last authors, to FAPESC for financially supporting this study through PAP/UDESC and to Instituto Chico Mendes de Conservação da Biodiversidade for allowing the execution of this project in the São Joaquim National Park, as well as to the Park administration.

\section{REFERENCES}

Alvarez-Añorve MY, M Quesada, GA Sánchez-Azofeifa, LD Avila-Cabadilla, JA Gamon. 2012. Functional regeneration and spectral reflectance of trees during succession in a highly diverse tropical dry forest ecosystem. American Journal of Botany 99(5): 816-826. DOI: https://doi. org/10.3732/ajb.1100200.

Arroyo-Rodríguez V., FPL Melo, M Martínez-Ramos, F Bongers, RL Chazdon, JA Meave, N Norden, BA Santos, IR Leal, M Tabarelli. 2017. Multiple successional pathways in human-modified tropical landscapes: new insights from forest succession, forest fragmentation and landscape ecology research. Biological Reviews 92(1): 326-340. DOI: https:// doi.org/10.1111/brv.12231.

Boeger MRT, C Biu, R Goldenberg. 2009. Arquitetura foliar comparativa de Miconia sellowiana (DC.) Naudin (Melastomataceae) em diferentes fitofisionomias no Estado do Paraná, Brasil. Acta Botanica Brasilica 23(3): 657-665. DOI: https://doi.org/10.1590/S0102-33062009000300005

Carlucci M, FZ Teixeira, FT Brum, LDS Duarte. 2011. Edge expansion of Araucaria forest over southern Brazilian grasslands relies on nurse plant effect. Community Ecology 12(2): 196-201. DOI: https://doi.org/10.1556/ ComEc.12.2011.2.7

Carvalho PER. 2003. Espécies arbóreas brasileiras. v. 1. Brasília. Embrapa Informação Tecnológica. 1039 p.

Chave J, HC Muller-Landau, TR Baker, TA Easdale, H ter Steege, CO Webb. 2006. Regional and phylogenetic variation of wood density across 2456 neotropical tree species. Eco- logical Applications 16(6): 2356-2367. DOI: https://doi. org/10.1890/1051-0761\%282006\%29016\%5B2356\%3AR APVOW\%5D2.0.CO\%3B2.

Cornelissen JHC, S Lavorel, E Garnier, S Diaz, N Buchmann, DE Gurvich, PB Reich, H ter Steege, HD Morgan, MGA van der Heijden, JG Pausas, H Poorter. 2003. Handbook of protocols for standardised and easy measurement of plant functional traits worldwide. Australian Journal of Botany 51(4): 335-380. DOI: https://doi.org/10.1071/BT02124.

Cornwell WK, JH Cornelissen, K Amatangelo, E Dorrepaal, VT Eviner, O Godoy, SE Hobbie, B Hoorens, H Kurokawa, N Pérez-Harguindeguy, HM Quested, LS Santiago, DA Wardle, IJ Wright, R Aerts, SD Allison, P van Bodegom, V Brovkin, A Chatain, TV Callaghan, S Díaz, E Garnier, DE Gurvich, E Kazakou, JA Klein, J Read, PB Reich, NA Soudzilovskaia, MV Vaieretti, M Westoby. 2008. Plant species traits are the predominant control on litter decomposition rates within biomes worldwide. Ecology Letters 11(10): 1065-1071. DOI: https://doi.org/10.1111/j.1461-0248.2008.01219.x.

Donovan LA, H Maherali, CM Caruso, H Huber, H Kroon. 2011. The evolution of the worldwide leaf economics spectrum. Trends in Ecology and Evolution 26(2): 88-95. DOI: https:// doi.org/10.1016/j.tree.2010.11.011.

Dreyer JBB, Schlickmann MB, Cuchi T, Vieira FS, Moraes GC, Higuchi P, Silva AC. 2020. Estruturação espacial de traços funcionais de espécies arbóreas em função da distância da borda em Floresta Altomontana no sul do Brasil. Ciência Florestal 30(2) (in press). DOI: https://doi. org/10.5902/1980509833586

Duarte E, AC Silva, P Higuchi, JG Larsen, DC Ortiz, A Gross, E Turmina, JT Aguiar, MB Vefago, CR Schneider, SF Siqueira, AC Lemos, L Ribeiro. 2018. Sucessão em fragmentos florestais altomontanos no sul do Brasil: uma abordagem florístico-estrutural e filogenética. Ciência Florestal 28(3): 898-912. DOI: https://doi.org/10.5902/1980509833349.

França GS, JR Stehmann. 2004. Composição florística e estrutura do componente arbóreo de uma floresta altimontana no município de Camanducaia, Minas Gerais, Brasil. Revista Brasileira de Botânica 27(1): 19-30. DOI: https://doi. org/10.1590/S0100-84042004000100003.

Galvão F, C Augustin. 2001. A gênese dos campos sulinos. Floresta 41(1): 191-200. DOI: https://doi.org/10.5380/ rf.v41i1.21202.

Givnish TJ. 1987. Comparative studies of leaf form: assessing the relative roles of selective pressures and phylogenetic constraints. New Phytologist 106(1): 131-160. DOI: https:// doi.org/10.1111/j.1469-8137.1987.tb04687.x.

Grime JP. 1977. Evidence for the existence of three primary strategies in plants and its relevance to ecological and evolutionary theory. The American Naturalist 111(982): 1169-1194. DOI: https://doi.org/10.1086/283244.

Hill MO, Smith AJE. 1976. Principal component analysis of taxonomic data with multi-state discrete characters. Taxon 25: 249-255.

Lebrija-Trejos E, EA Pérez-García, JA Meave, F Bongers, L Poorter. 2011. Functional traits and environmental filtering drive community assembly in a species-rich tropical system. Ecology 91(2) 386-398. DOI: https://doi. org/10.1890/08-1449.1.

Lohbeck M, L Poorter, M Martínez-Ramos, J Rodriguez-Velázquez, M van Breugel, F Bongers. 2014. Changing drivers 
of species dominance during tropical forest succession. Functional Ecology 28(4): 1052-1058. DOI: https://doi. org/10.1111/1365-2435.12240.

Mason NWH, D Mouillot, WG Lee, JB Wilson. 2005. Functional richness, functional eveness and functional divergence: the primary components of functional diversity. Oikos 111(1): 112118. DOI: https://doi.org/10.1111/j.0030-1299.2005.13886.x

Michaud JP, KG Schoenly, G Moreau. 2015. Rewriting ecological succession history: did carrion ecologists get there first? The Quarterly Review of Biology 90(1): 45-66. DOI: https://doi.org/10.1111/j.0030-1299.2005.13886.x.

Pérez-Harguindeguy N, S Díaz, E Garnier, S Lavorel, H Poorter, P Jaureguiberry, MS Bret-Harte, WK Cornwell, JM Craine, DE Gurvich, C Urcelay, EJ Veneklaas, PB Reich, L Poorter, IJ Wright, P Ray, L Enrico, JG Pausas, AC de Vos, N Buchmann, G Funes, F Quétier, JG Hodgson, K Thompson, HD Morgan, H ter Steege, MGA van der Heijden, L Sack, B Blonder, P Poschlod, MV Vaieretti, G Conti, AC Staver, S Aquino, JHC Cornelissen. 2013. New handbook for standardised measurement of plant functional traits worldwide. Australian Journal of Botany 61(3): 167-234. DOI: https:// doi.org/10.1071/BT12225_CO.

R Core Team. 2019. R: A language and environment for statistical computing. R Foundation for Statistical Computing. Consultado 22 abr. 2019. Disponible em http://www.r-project.org

Reich PB, MB Walters, DS Ellsworth. 1992. Leaf life-span in relation to leaf, plant, and stand characteristics among diverse ecosystems. Ecological Monographs 62(3): 365-392. DOI: https://doi.org/10.2307/2937116.
Schantz MC, RL Sheley, JJ James. 2015. Role of propagule pressure and priority effects on seedlings during invasion and restoration of shrub-steppe. Biological Invasions 17(1): 7385. DOI: https://doi.org/10.1007/s10530-014-0705-2.

Silveira MF, Silva AC, Duarte E, Muzeka LM, Larsen JG, Santos V, Lovatel QC, Higuchi P. Supplementary files related to the paper "Functional composition of subtropical highland forests in different successional stages in southern Brazil", 2021. Accessed 10 Jan. 2021. DOI: https://github.com/higuchip/mayara paper.

Soboleski VF, P Higuchi, AC Silva, R Loebens, K Souza, F Buzzi Junior, CL Lima, AP Cruz, MAF Silva, JP Dallabrida. 2017. Variação de atributos funcionais do componente arbóreo em função de gradientes edáficos em uma floresta nebular no sul do Brasil. Rodriguésia 68(2): 291-300. DOI: https://doi.org/10.1590/2175-7860201768201.

Turner IM. 2001. The ecology of trees in the tropical rain forest. Cambridge. Cambridge University Press. 298 p. DOI: 10.1017/CBO9780511542206

Walker B, A Kinzig, J Langridge. 1999. Plant attribute diversity, resilience, and ecosystem function: the nature and significance of dominant and minor species. Ecosystems 2(2): 95113. DOI: https://doi.org/10.1007/s100219900062.

Zanne AE, M Westoby, DS Falster, DD Ackerly, SR Loarie, SE Arnold, DA Coomes. 2010. Angiosperm wood structure: global patterns in vessel anatomy and their relation to wood density a potential conductivity. American Journal of Botany 92(2): 207-215. DOI: https://doi.org/10.3732/ ajb.0900178 
